Article

\title{
Promotive Effect of $\mathrm{Sn}^{2+}$ on $\mathrm{Cu}^{0} / \mathrm{Cu}^{+}$Ratio and Stability Evolution of $\mathrm{Cu} / \mathrm{SiO}_{2}$ Catalyst in the Hydrogenation of Dimethyl Oxalate
}

\author{
Chuancai Zhang ${ }^{1}$, Denghao Wang ${ }^{2}$ and Bin Dai ${ }^{2, *}$ \\ 1 School of Chemical Engineering and Technology, Tianjin University, Tianjin 300072, China; \\ zhangchuanc111@126.com \\ 2 School of Chemistry and Chemical Engineering of Shihezi University, Shihezi 832000, China; \\ JayGatsby@stu.shzu.edu.cn \\ * Correspondence: db_tea@shzu.edu.cn; Tel.: +86-993-205-7277
}

Academic Editor: Rajendra S. Ghadwal

Received: 26 March 2017; Accepted: 14 April 2017; Published: 19 April 2017

\begin{abstract}
The influence of $\mathrm{Sn}^{2+}$ doping on the structure and performance of silica supported copper catalyst was systematically investigated and characterised. Catalytic evaluation showed that the suitable content of $\mathrm{Sn}^{2+}$ introduced into a $\mathrm{Cu} / \mathrm{SiO}_{2}$ catalyst evidently improved the catalytic activity and stability of ethylene glycol synthesis from dimethyl oxalate. X-ray diffraction and X-ray auger electron spectroscopy indicated that the $\mathrm{Cu}^{0} / \mathrm{Cu}^{+}$ratio gradually increased with increasing $\mathrm{Sn}^{2+}$ content, and an appropriate proportion of $\mathrm{Cu}^{0} / \mathrm{Cu}^{+}$ratio played a very significant role in this reaction. Transmission electron microscopy revealed that the active copper particles in the $\mathrm{Cu}-x \mathrm{Sn} / \mathrm{SiO}_{2}$ catalyst were smaller than those of the $\mathrm{Cu} / \mathrm{SiO}_{2}$ catalyst. This result may be due to the introduction of $\mathrm{Sn}^{2+}$ species transformed into $\mathrm{SnO}_{2}$. Furthermore, $\mathrm{SnO}_{2}$ effectively segregated the active copper. These effects are beneficial in inhibiting the aggregation of copper in the catalysts, thereby improving the stability of the catalyst and prolonging the life span.
\end{abstract}

Keywords: $\mathrm{Cu}-x \mathrm{Sn} / \mathrm{SiO}_{2}$; dimethyl oxalate; hydrogenation; $\mathrm{Cu}^{0} / \mathrm{Cu}^{+}$ratio; stability

\section{Introduction}

Hydrogenation of dimethyl oxalate (DMO) to ethylene glycol (EG) with coal as raw material is of industrial interest. This process has also become an important research topic considering various applications of EG and the growing market outlook. Copper-supported catalysts show potential catalytic activities for hydrogenation of DMO [1-3]. Copper catalyst exhibits high activity and selectivity for EG synthesis from DMO. However, the stability of the catalyst remains to be improved. Several factors, including metal dispersion, $\mathrm{Cu}^{0} / \mathrm{Cu}^{+}$ratio, metal-support interaction, active-component sintering and carbon deposition, affect the stability of the catalyst [4-8]. Given the difficulty of improving the stability with a single copper catalyst, copper is modified by a second additive $(\mathrm{Cr}, \mathrm{Ni}, \mathrm{B}, \mathrm{Zn}, \mathrm{Cu}, \mathrm{Ag}, \mathrm{Co}$ and $\mathrm{La})$, which favours catalytic stability in several recent studies [9-11]. In spite of some progress in this research direction, further study remains necessary. In addition, the use of tin additives to improve the stability of copper catalysts for hydrogenation of DMO to EG is seldom reported.

Sn species is a kind of promoter that improves the dispersion of active metals and stability of the catalyst [12-15]. Wang et al., reported that the selectivity and stability of isobutane dehydrogenation can be significantly enhanced by the addition of tin in $\mathrm{Ni} / \mathrm{SiO}_{2}$ catalyst [16]. Such improvement is ascribed to the fact that tin doping can successfully reduce the size of nickel particles, and the presence of $\mathrm{SnO}_{\mathrm{x}}$ suppresses the migration of carbon deposition to prolong the lifetime. De Oliveira et al. found 
that a Co-Sn $/ \mathrm{ZnO}_{2}$ catalyst with an atomic $\mathrm{Sn} / \mathrm{Co}$ ratio of 1 exhibits the most desirable activity and selectivity for the hydrogenation of methyl oleate to oleyl alcohol [17]. Furthermore, the selectivity to unsaturated alcohol is considerably improved by doping tin to cobalt. These results indicated that the addition of tin in the catalyst may play a positive role in the hydrogenation of esters to alcohols. In addition, $\mathrm{Sn}^{2+}$ could play a certain role in adjusting the $\mathrm{Cu}^{0} / \mathrm{Cu}^{+}$ratio in view of its strong reduction which is considered to influence the hydrogenation of DMO to EG.

In the present study, we aimed to investigate and explain the effect of $\mathrm{Sn}^{2+}$ content on metal dispersion, $\mathrm{Cu}^{0} / \mathrm{Cu}^{+}$ratio and catalytic stability evolution of $\mathrm{Cu}-x \mathrm{Sn} / \mathrm{SiO}_{2}$ catalysts during EG synthesis from DMO. We synthesised $\mathrm{Cu} / \mathrm{SiO}_{2}$ catalysts and impregnated different $\mathrm{Sn}^{2+}$ contents onto these catalysts to generate $\mathrm{Cu}-x \mathrm{Sn} / \mathrm{SiO}_{2}$. The $\mathrm{Sn}^{2+}$ content was adjusted over the range $0.3-2 \%$. Consequently, part of $\mathrm{Cu}^{+}$was effectively reduced to $\mathrm{Cu}^{0}$ due to the reduction of $\mathrm{Sn}^{2+}$. Therefore, we adjusted and optimised the $\mathrm{Cu}^{0} / \mathrm{Cu}^{+}$ratio. We also embedded $\mathrm{Sn}$ species onto the surface of the catalyst to help separate and partially fix the copper. The catalytic activity and stability of the catalyst were obviously enhanced with Sn doping when compared with that of the $\mathrm{Cu} / \mathrm{SiO}_{2}$ catalyst. Low-temperature $\mathrm{N}_{2}$ adsorption (Brunauer-Emmett-Teller (BET) method), transmission electron microscopy (TEM), X-ray diffraction (XRD), temperature-programmed reduction (TPR), X-ray photoelectron spectroscopy (XPS), X-ray auger electron spectroscopy (XAES) and inductively coupled plasma atomic emission spectrometry (ICP-AES) were used to analyse the structures and properties of the catalysts. Moreover, we investigated in detail the influence of Sn promoter on the structural changes and catalytic performance improvements in $\mathrm{Cu} / \mathrm{SiO}_{2}$.

\section{Results and Discussion}

\subsection{Characterisation of the Catalysts}

The textural structures and chemical compositions of $\mathrm{Cu} / \mathrm{SiO}_{2}$ and $\mathrm{Cu}-\mathrm{Sn} / \mathrm{SiO}_{2}$ catalysts after calcination at $450{ }^{\circ} \mathrm{C}$ for $5 \mathrm{~h}$ were analysed by ICP-AES. The actual amount of copper in the catalyst was about $11 \%$ (Table 1), which may be due in part to the residual copper in the solution. Another part of the weakly adsorbed copper on silicon dioxide was subsequently washed off. Tin loading was basically equal to the theoretical value because of the use of the impregnation method without loss of tin solution.

Table 1. Lists of the chemical compositions and textural features of the reduced $\mathrm{Cu} / \mathrm{SiO}_{2}$ and $\mathrm{Cu}-x \mathrm{Sn} / \mathrm{SiO}_{2}$.

\begin{tabular}{cccccc}
\hline Sample & $\mathbf{C u}(\mathbf{w t} \mathbf{\%})$ & $\mathbf{S n}(\mathbf{w t} \mathbf{\%})$ & $\boldsymbol{S}_{\text {BET }}\left(\mathbf{m}^{\mathbf{2}} \cdot \mathbf{g}^{-\mathbf{1}}\right)$ & $\boldsymbol{V}_{\text {pore }}\left(\mathbf{c m}^{\mathbf{3}} \cdot \mathbf{g}^{-\mathbf{1}}\right)$ & $\boldsymbol{D}_{\text {pore }}(\mathbf{n m})$ \\
\hline $\mathrm{Cu} / \mathrm{SiO}_{2}$ & 10.94 & - & 246.7 & 0.67 & 10.1 \\
$\mathrm{Cu}-0.3 \% \mathrm{Sn} / \mathrm{SiO}_{2}$ & 10.82 & 0.29 & 244.9 & 0.65 & 10.2 \\
$\mathrm{Cu}-0.6 \% \mathrm{Sn} / \mathrm{SiO}_{2}$ & 10.86 & 0.58 & 244.3 & 0.64 & 10.2 \\
$\mathrm{Cu}-1.2 \% \mathrm{Sn} / \mathrm{SiO}_{2}$ & 10.81 & 1.18 & 236.3 & 0.62 & 10.3 \\
$\mathrm{Cu}-1.8 \% \mathrm{Sn} / \mathrm{SiO}_{2}$ & 10.79 & 1.82 & 221.8 & 0.59 & 10.5 \\
\hline
\end{tabular}

Figure 1 shows the $\mathrm{N}_{2}$ adsorption-desorption profiles and Barrett-Joyner-Halenda (BJH) pore size distribution curves of $\mathrm{Cu} / \mathrm{SiO}_{2}$ and $\mathrm{Cu}-x \mathrm{Sn} / \mathrm{SiO}_{2}$ catalysts. The $\mathrm{N}_{2}$ adsorption-desorption isotherms of all the catalysts belonged to type IV. The profiles of the $\mathrm{N}_{2}$ adsorption-desorption and $\mathrm{BJH}$ pore size distribution between $\mathrm{Cu} / \mathrm{SiO}_{2}$ and the $\mathrm{Cu}-x \mathrm{Sn} / \mathrm{SiO}_{2}$ catalysts showed no obvious change. This result indicated that the catalyst retained the type IV isotherms with shape similar to that of the H-type hysteresis loop.

The $S_{\text {BET }}$ was in the range of $221.8-246.7 \mathrm{~m}^{2} \cdot \mathrm{g}^{-1}$. The specific surface area of the catalysts decreased from 246.7 to $221.8 \mathrm{~m}^{2} \cdot \mathrm{g}^{-1}$ when the Sn content increased from $0.3 \%$ to $1.8 \%$. This observation suggested that a small amount of Sn doping slightly affected the $S_{\mathrm{BET}}$ of the catalysts. 

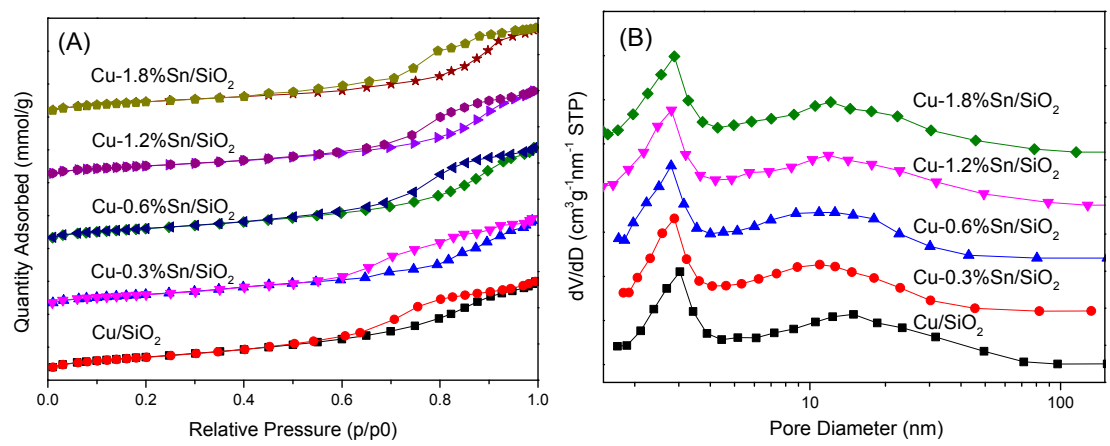

Figure 1. $\mathrm{N}_{2}$ adsorption-desorption profiles (A) and Barrett-Joyner-Halenda (BJH) pore-size distribution curves $(\mathbf{B})$ of calcined $\mathrm{Cu} / \mathrm{SiO}_{2}$ and $\mathrm{Cu}-x \mathrm{Sn} / \mathrm{SiO}_{2}$ catalysts.

The curve of the $\mathrm{BJH}$ pore size distribution showed that the catalyst possessed a double mesoporous structure. The average pore size of the catalysts was in the range of 10.1-10.5 nm, and the pore volumes ranged within $0.59-0.67 \mathrm{~cm}^{3} \cdot \mathrm{g}^{-1}$. The average pore size of the catalyst increased with increasing tin content, whereas the pore volumes gradually decreased. This effect may have resulted from the partial covering of tin on the catalyst surface and the slight blocking of hole channels.

$\mathrm{H}_{2}$-TPR measurements were performed in order to study the reducibility of $5 \% \mathrm{Sn} / \mathrm{SiO}_{2}, \mathrm{Cu} / \mathrm{SiO}_{2}$ and $\mathrm{Cu}-x \mathrm{Sn} / \mathrm{SiO}_{2}$ catalysts (Figure 2). For $5 \% \mathrm{Sn} / \mathrm{SiO}_{2}$ catalyst, TPR showed two weak peaks at around 400 and $500{ }^{\circ} \mathrm{C}$, which should be attributed to the reduction peak of tin oxides. It is obvious that tin oxides supported on silica are difficult to reduce at low temperature. Two reduction peaks can be observed in the $\mathrm{Cu} / \mathrm{SiO}_{2}$ catalyst. One sharp and large reduction peak at about $239{ }^{\circ} \mathrm{C}$ was attributed to the highly dispersed $\mathrm{CuO}$. Another weak peak located at around $300{ }^{\circ} \mathrm{C}$ was related to the reduction of large-particle $\mathrm{CuO}[18,19]$. For $\mathrm{Cu}-x \mathrm{Sn} / \mathrm{SiO}_{2}$ catalysts, three reduction peaks could be observed. The low and middle temperature reduction peaks corresponded to the reduction of cupric oxide, while the peak detected at $400-500{ }^{\circ} \mathrm{C}$ could be ascribed to the reduction of tin oxides. The first large reduction peak of the $\mathrm{Cu}-x \mathrm{Sn} / \mathrm{SiO}_{2}$ catalysts gradually shifted to the low-temperature with increasing tin content compared with the $\mathrm{Cu} / \mathrm{SiO}_{2}$ catalyst. This finding illustrated that part of the copper species was likely reduced by $\mathrm{Sn}^{2+}$ which confirmed that $\mathrm{Sn}^{2+}$ doping was favorable for the reduction of $\mathrm{CuO}$. The third reduction peak at high temperature that belongs to the reduction of tin oxide was considerably weak due to the low content of Sn doping.

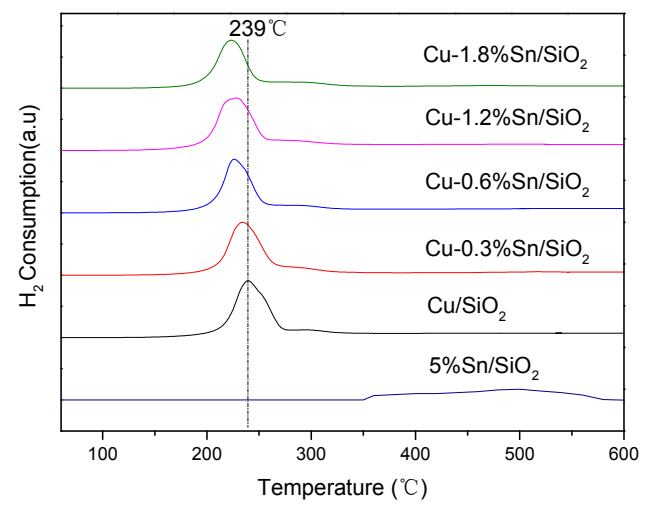

Figure 2. $\mathrm{H}_{2}$-temperature-programmed reduction of $5 \% \mathrm{Sn} / \mathrm{SiO}_{2}, \mathrm{Cu} / \mathrm{SiO}_{2}$ and $\mathrm{Cu}-x \mathrm{Sn} / \mathrm{SiO}_{2}$ catalysts after calcination at $300^{\circ} \mathrm{C}$.

To investigate the possible $\mathrm{Sn}^{2+}$ doping-induced phase changes between $\mathrm{Cu}^{0}$ and $\mathrm{Cu}^{+}$, all reduced $\mathrm{Cu} / \mathrm{SiO}_{2}$ and $\mathrm{Cu}-x \mathrm{Sn} / \mathrm{SiO}_{2}$ catalysts were analysed by $\mathrm{XRD}$. Four diffraction peaks were observed in all of the catalysts (Figure 3). These diffraction peaks of $2 \theta$ were located at $21.7^{\circ}, 36.4^{\circ}, 43.3^{\circ}$ and $50.4^{\circ}$. 
The first diffraction peak at $2 \theta$ of $21.7^{\circ}$ exhibited an amorphous silica structure. The peak position was located at the $2 \theta$ of $36.4^{\circ}$ attached to the $\mathrm{Cu}_{2} \mathrm{O}$ phase. The two other diffraction peaks at the $2 \theta$ of $36.4^{\circ}$ and $43.3^{\circ}$ belonged to metallic $\mathrm{Cu}$. The diffraction peaks of $\mathrm{Cu}$ and $\mathrm{Cu}_{2} \mathrm{O}$ were relatively weak, thereby suggesting that copper particles were remarkably small, and $\mathrm{Cu}$ species were well dispersed on the surface of the supports. The diffraction peaks of cuprous oxide evidently decreased gradually with increasing amount of tin doping, whereas the peak of copper increased gradually. This result indicated that part of $\mathrm{Cu}^{+}$was reduced to $\mathrm{Cu}^{0}$, and the $\mathrm{Cu}^{0} / \mathrm{Cu}^{+}$ratio was effectively adjusted. No obvious diffraction peak was detected for $\mathrm{Sn}$ and $\mathrm{SnO}_{2}$ phases, which may be due to the low level of $\mathrm{Sn}^{2+}$ doping in the catalysts.

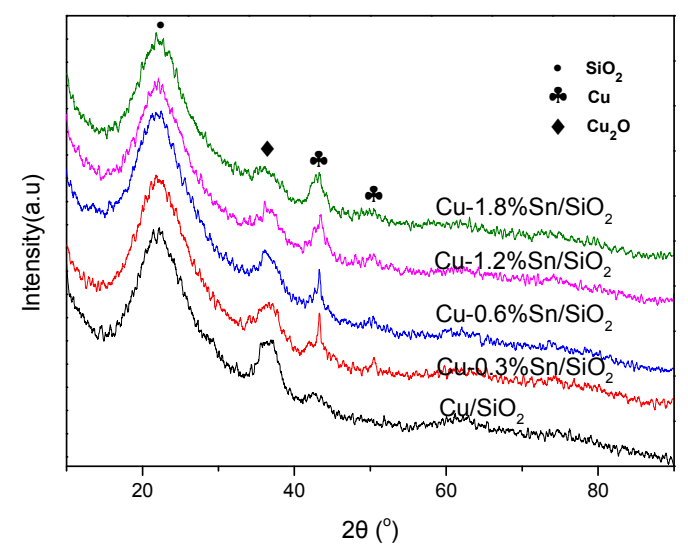

Figure 3. X-ray diffraction patterns of the reduced catalysts.

The TEM images of the reduced $\mathrm{Cu} / \mathrm{SiO}_{2}$ with and without $\mathrm{Sn}$ doping are presented in Figure 4 . For all the catalysts, the supports involved numerous irregular spheres of $\sim 20 \mathrm{~nm}$ diameter, and the metallic nanoparticles resembled small black spots scattered on the surface of the supports. The average particle sizes of the metal nanoparticles of the $\mathrm{Cu} / \mathrm{SiO}_{2}$ and $\mathrm{Cu}-x \mathrm{Sn} / \mathrm{SiO}_{2}$ catalysts were $4.33,3.31$, $3.68,3.13$ and $3.21 \mathrm{~nm}$. The copper particles in the $\mathrm{Cu}-x \mathrm{Sn} / \mathrm{SiO}_{2}$ catalysts were smaller than those of the $\mathrm{Cu} / \mathrm{SiO}_{2}$, which may be due to the conversion of $\mathrm{Sn}^{2+}$ to $\mathrm{SnO}_{2}$ during immersion. Furthermore, tin oxide hindered the growth and aggregation of active copper particles in hydrogen reduction at low temperatures.
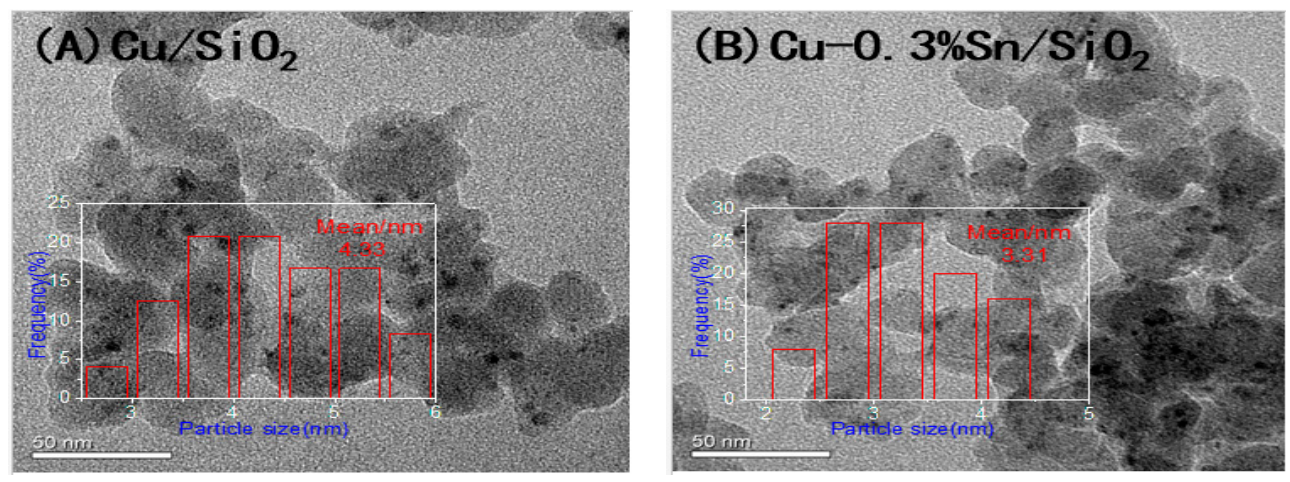

Figure 4. Cont. 

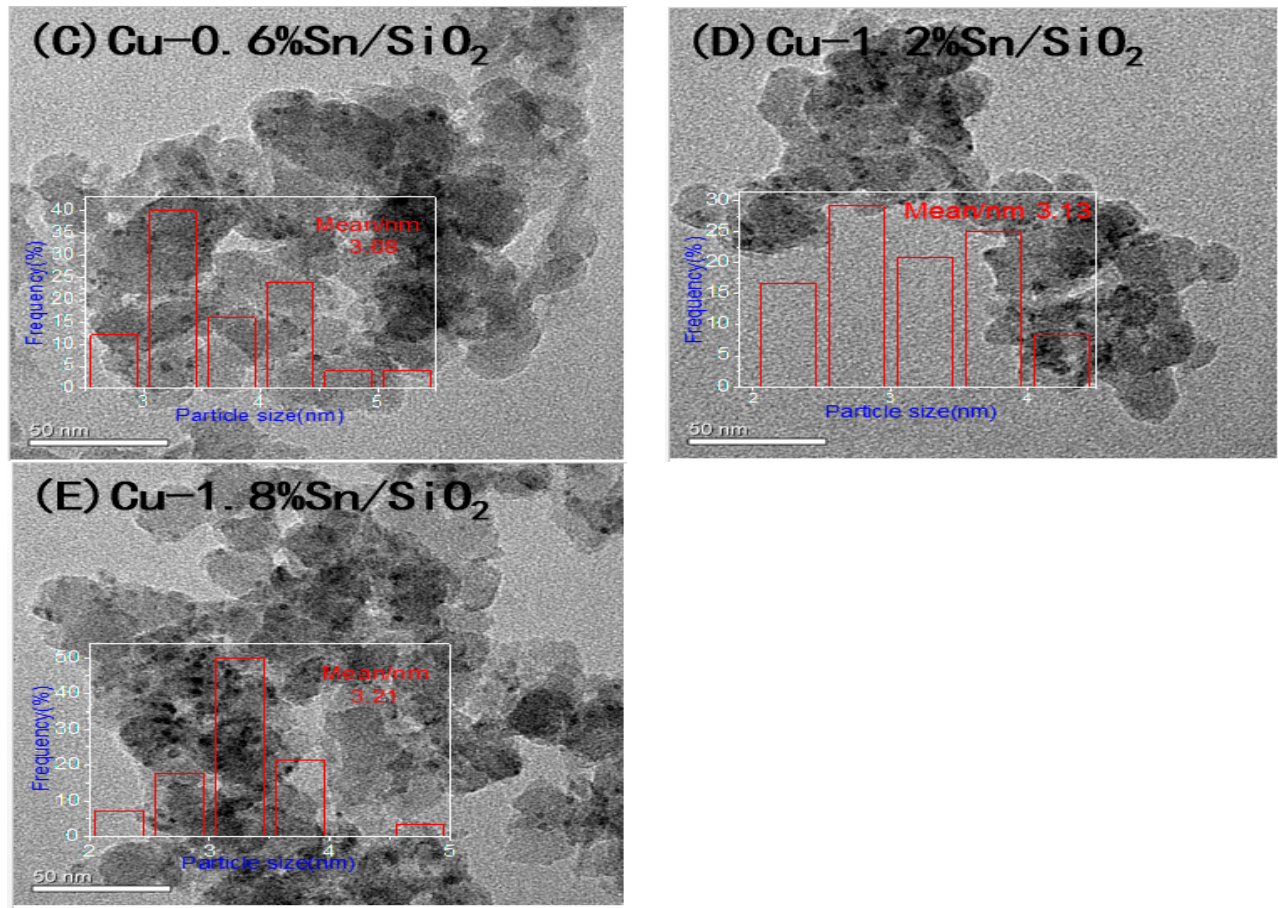

Figure 4. The TEM images of the reduced catalysts: (A) $\mathrm{Cu} / \mathrm{SiO}_{2}$, (B) $\mathrm{Cu}-0.3 \% \mathrm{Sn} / \mathrm{SiO}_{2}$, (C) $\mathrm{Cu}-0.6 \% \mathrm{Sn} / \mathrm{SiO}_{2}$, (D) $\mathrm{Cu}-1.2 \% \mathrm{Sn} / \mathrm{SiO}_{2}$ and (E) $\mathrm{Cu}-1.8 \% \mathrm{Sn} / \mathrm{SiO}_{2}$.

\subsection{Catalytic Activity and Stability}

The experiments on DMO hydrogenation were carried out to study the effect of tin doping on the catalytic performance of copper catalyst. Figure 5 shows the comparison of DMO conversion (Figure 5A) and EG selectivity (Figure $5 \mathrm{~B}$ ) in $\mathrm{Cu} / \mathrm{SiO}_{2}$ and $\mathrm{Cu}-x \mathrm{Sn} / \mathrm{SiO}_{2}$ catalysts with varied weight liquid hour space velocity (WLHSVs). The reaction conditions were $2.5 \mathrm{MPa} \mathrm{H}_{2}, 200{ }^{\circ} \mathrm{C}$ and $\mathrm{H}_{2} / \mathrm{DMO}$ ratio of 90. The catalytic performance exhibited a volcanic-like trend with the increase of tin doping in the copper catalysts. The $\mathrm{Cu}-0.6 \% \mathrm{Sn} / \mathrm{SiO}_{2}$ catalyst showed the most remarkable $\mathrm{DMO}$ conversion and EG selectivity, the conversion and selectivity of $\mathrm{Cu}-\mathrm{xSn} / \mathrm{SiO}_{2}$ catalyst with tin content higher than $1.2 \%$ evidently decreased, whereas the catalytic performance of $\mathrm{Cu}-1.8 \% \mathrm{Sn} / \mathrm{SiO}_{2}$ catalyst was the worst among all of the catalysts. This result may be due to excessive tin doping, which covered the copper surface and blocked the active site of the copper. Moreover, a large amount of $\mathrm{Cu}^{2+}$ was reduced to $\mathrm{Cu}^{0}$ with excessive $\mathrm{Sn}^{2+}$ so as to break the balance of $\mathrm{Cu}^{0}$ and $\mathrm{Cu}^{+}$.
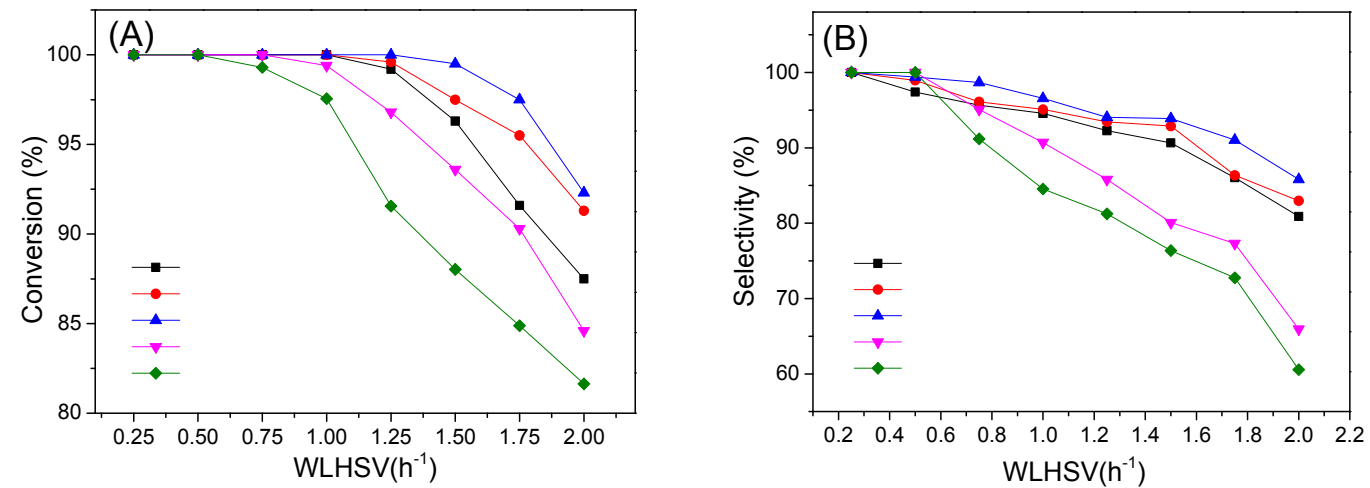

Figure 5. Comparison of dimethyl oxalate (DMO) conversion (A) and ethylene glycol (EG) selectivity (B) in $\mathrm{Cu} / \mathrm{SiO}_{2}$ and $\mathrm{Cu}-x \mathrm{Sn} / \mathrm{SiO}_{2}$ catalysts with varied WLHSVs. 
Long-duration experiments were employed to investigate the stability of the catalyst. A comparison of the DMO conversion and EG selectivity of the $\mathrm{Cu} / \mathrm{SiO}_{2}$ and $\mathrm{Cu}-0.6 \% \mathrm{Sn} / \mathrm{SiO}_{2}$ catalysts is shown in Figure 6. $\mathrm{Cu}-0.6 \% \mathrm{Sn} / \mathrm{SiO}_{2}$ exhibited satisfactory activity and lifetime. The DMO was completely transformed, the selectivity of EG was $96 \%$ in the $\mathrm{Cu}-0.6 \% \mathrm{Sn} / \mathrm{SiO}_{2}$ catalyst, and no decreasing trend was observed after about $200 \mathrm{~h}$ of reaction. However, the catalytic performance of $\mathrm{Cu} / \mathrm{SiO}_{2}$ declined evidently after $90 \mathrm{~h}$ of reaction. This result indicated that a reasonable content of $\mathrm{Sn}$ doping improves the stability of the catalyst.

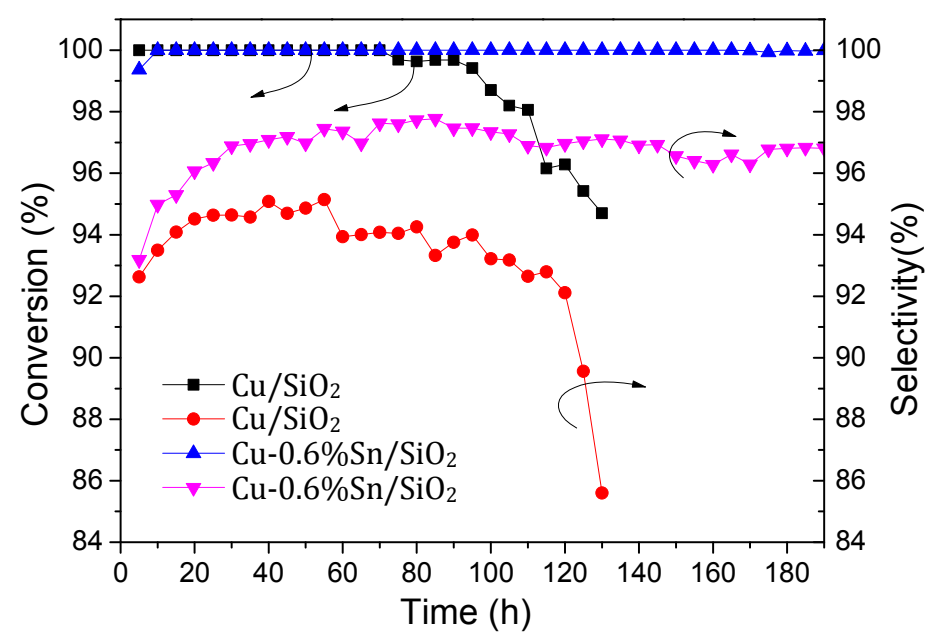

Figure 6. Long experimental periods of $\mathrm{Cu} / \mathrm{SiO}_{2}$ and $\mathrm{Cu}-\mathrm{x} 0.6 \% \mathrm{Sn} / \mathrm{SiO}_{2}$ catalysts. The reaction conditions were $2.5 \mathrm{MPa} \mathrm{H}_{2}, 200{ }^{\circ} \mathrm{C}, \mathrm{H}_{2}$ / DMO ratio of 90 and WLHSV of $1 \mathrm{~h}^{-1}$.

\subsection{Characterisation of the Used Catalysts}

To further investigate the reasons for improving the activity and stability, the XPS spectra of Sn $3 \mathrm{~d}_{5 / 2}$ and $\mathrm{Cu} 2 \mathrm{p}$ of $\mathrm{Cu} / \mathrm{SiO}_{2}$ and $\mathrm{Cu}-\mathrm{xSn} / \mathrm{SiO}_{2}$ catalysts for $8 \mathrm{~h}$ reaction were investigated. In Figure 7 , an asymmetric $\mathrm{Sn} 3 \mathrm{~d}_{5 / 2}$ peak at the binding energy (BE) of $487 \mathrm{eV}$ implied the existence of tin oxides in the $\mathrm{Cu}-\mathrm{xSn} / \mathrm{SiO}_{2}$ catalysts. Although the BEs of $\mathrm{Sn}^{2+}(486.5 \mathrm{eV})$ and $\mathrm{Sn}^{4+}(487.3 \mathrm{eV})$ were close and difficult to distinguish by XPS, we deduced that the oxidised tin species were mainly composed of $\mathrm{Sn}^{4+}$ because the reaction between $\mathrm{Sn}^{2+}$ and $\mathrm{Cu}^{2+}$ can produce $\mathrm{SnO}_{2}$ easily. By contrast, $\mathrm{SnO}_{2}$ is difficult to reduce by hydrogen during reduction at $300{ }^{\circ} \mathrm{C}$ and reaction at $200{ }^{\circ} \mathrm{C}$.

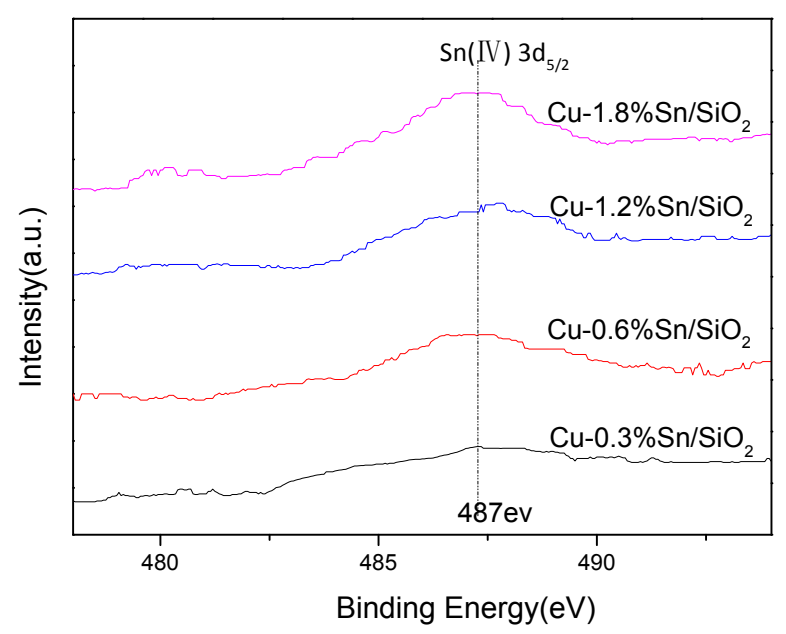

Figure 7. X-ray photoelectron spectroscopy (XPS) spectra of $\mathrm{Sn} 3 \mathrm{~d}_{5 / 2}$ of $\mathrm{Cu} / \mathrm{SiO}_{2}$ and $\mathrm{Cu}-\mathrm{xSn} / \mathrm{SiO}_{2}$ catalysts under an $8 \mathrm{~h}$ reaction. 
Figure 8 displays the XPS spectra of $\mathrm{Cu} 2 \mathrm{p}$ of $\mathrm{Cu} / \mathrm{SiO}_{2}$ and $\mathrm{Cu}-\mathrm{xSn} / \mathrm{SiO}_{2}$ catalysts under an $8 \mathrm{~h}$ reaction. The $\mathrm{BEs}$ of $\mathrm{Cu}^{0}$ (about $932.7 \mathrm{eV}$ ) and $\mathrm{Cu}^{+}$(about $932.5 \mathrm{eV}$ ) were located near each other. Hence, dividing the peaks of $\mathrm{Cu}^{0}$ and $\mathrm{Cu}^{+}$was difficult. Conversely, the peak of $\mathrm{Cu}^{0}$ and $\mathrm{Cu}^{+}$can be distinguished effectively by XAES with peak fitting.

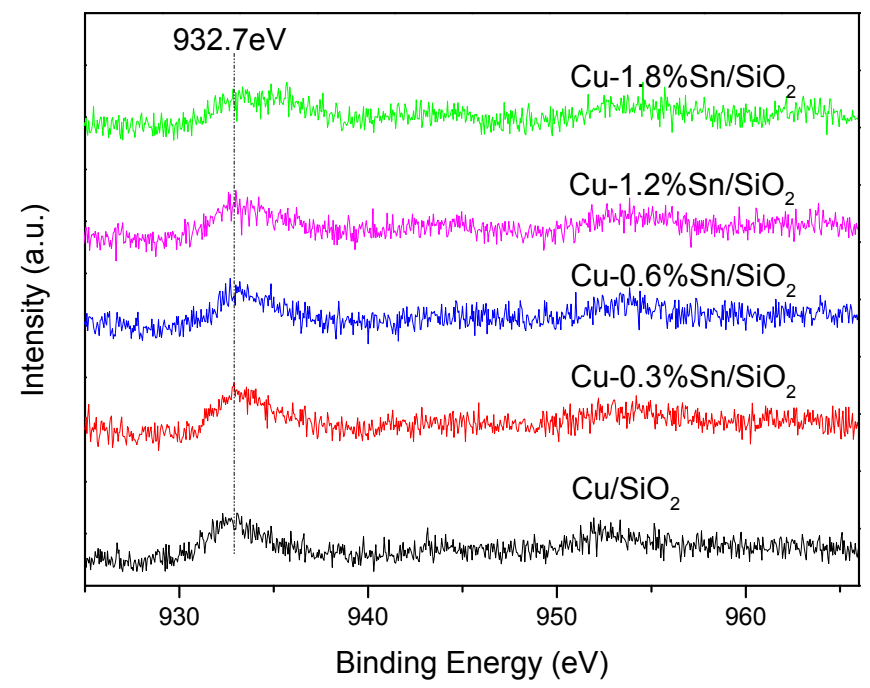

Figure 8. XPS spectra of $\mathrm{Cu} 2 \mathrm{p}$ of $\mathrm{Cu} / \mathrm{SiO}_{2}$ and $\mathrm{Cu}-\mathrm{xSn} / \mathrm{SiO}_{2}$ catalysts under an $8 \mathrm{~h}$ reaction.

Figure 9 presents the $\mathrm{Cu}$ LMM XAES profiles of these catalysts after $8 \mathrm{~h}$ reaction. A wide but asymmetrical folding peak with kinetic energy ranging from 907 to $924 \mathrm{eV}$ was observed in each catalyst. Two symmetrical peaks located at approximately 916.2 and $918.6 \mathrm{eV}$ and related to $\mathrm{Cu}^{+}$and $\mathrm{Cu}^{0}$ were fitted and distinguished by a peak separation software. The peak areas of $\mathrm{Cu}^{0}$ and $\mathrm{Cu}^{+}$ were calculated, and we found the proportion of $\mathrm{Cu}^{0}$ and $\mathrm{Cu}^{+}$to increase with increasing Sn content. The $\mathrm{Cu}^{0} / \mathrm{Cu}^{+}$ratios in the $\mathrm{Cu} / \mathrm{SiO}_{2}$ and $\mathrm{Cu}-\mathrm{xSn} / \mathrm{SiO}_{2}$ catalysts were $0.85,0.96,1.06,1.17$ and 1.23. This result suggested that a part of $\mathrm{Cu}^{2+}$ was reduced to $\mathrm{Cu}^{0}$ because of doping $\mathrm{Sn}^{2+}$, which played an effective role in regulating the $\mathrm{Cu}^{0} / \mathrm{Cu}^{+}$ratio. $\mathrm{Cu}^{0}$ is responsible for activate hydrogen and ester, and $\mathrm{Cu}^{+}$is believed to be polarized by $\mathrm{C}=\mathrm{O}$ bonds in the ester and is favourable for the formation and stabilization of the intermediate states. Accordingly, an appropriate $\mathrm{Cu}^{+} / \mathrm{Cu}^{0}$ ratio is highly important to the reaction. However, there are different views on the $\mathrm{Cu}^{+} / \mathrm{Cu}^{0}$ ratio. Some literatures reported that $\mathrm{Cu}^{+} / \mathrm{Cu}^{0}>1$ is beneficial for hydrogenation of DMO to EG, but the opposite view is also presented $[2,5,20]$. In order to explain this phenomenon rationally, Ma et al. investigated and found that there is a dynamic cycle between $\mathrm{Cu}^{0}$ and $\mathrm{Cu}^{+}$during ester hydrogenation. $\mathrm{Cu}^{0}$ can be oxidised to $\mathrm{Cu}^{+}$by ester, while $\mathrm{H}_{2}$ can also reduce $\mathrm{Cu}^{+}$into $\mathrm{Cu}^{0}$ in the reaction [21]. LaGrow et al. also observed the interface transition of $\mathrm{Cu}$ and $\mathrm{Cu}_{2} \mathrm{O}$ using ESTEM via switching hydrogen and oxygen environments [22]. It is reasonable to explain why different catalytic systems have different $\mathrm{Cu}^{+} / \mathrm{Cu}^{0}$ ratios that are favorable for the reaction; that may be why the $\mathrm{Cu}-0.6 \% \mathrm{Sn} / \mathrm{SiO}_{2}$ catalyst with the $\mathrm{Cu}^{0} / \mathrm{Cu}^{+}$ratio of 1.06 has the best catalytic activity and stability in our catalysts.

The TEM images of used $\mathrm{Cu} / \mathrm{SiO}_{2}(130 \mathrm{~h})$ and $\mathrm{Cu}-0.6 \% \mathrm{Sn} / \mathrm{SiO}_{2}(200 \mathrm{~h})$ catalysts after long-time tests are shown in Figure 10. Notably, the average particle size of the monometallic copper catalyst increased from 4.33 to $7.91 \mathrm{~nm}$ and that of $\mathrm{Cu}-0.6 \% \mathrm{Sn} / \mathrm{SiO}_{2}$ catalysts increased from 3.68 to $5.48 \mathrm{~nm}$. This result indicated that tin doping helps prevent the growth of copper particles during the reaction. 


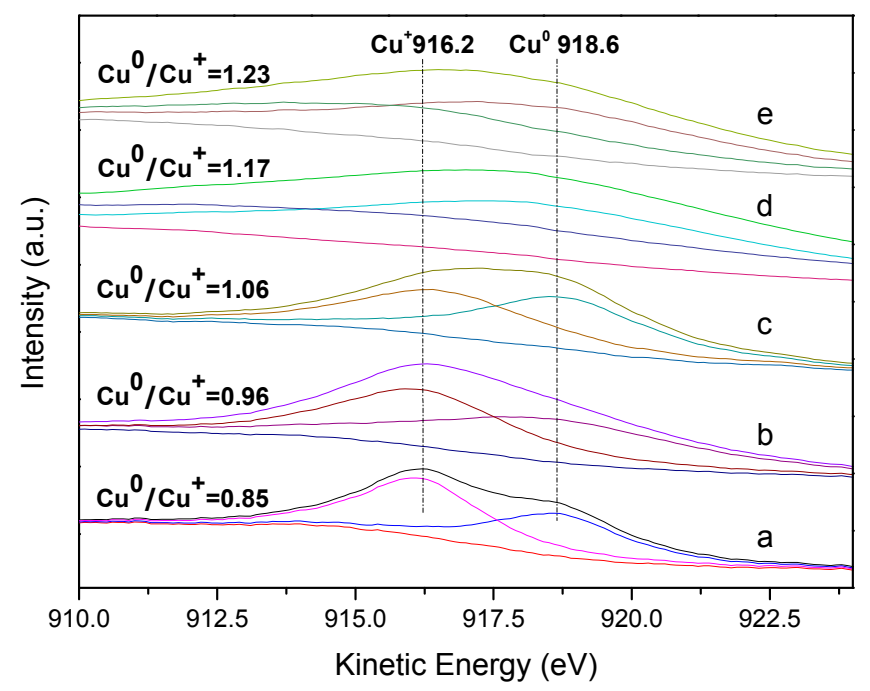

Figure 9. Curve fitting results of the $\mathrm{Cu}$ LMM XAES spectra of catalysts: (a) $\mathrm{Cu} / \mathrm{SiO}_{2}$, (b) $\mathrm{Cu}-0.3 \% \mathrm{Sn} / \mathrm{SiO}_{2}$, (c) $\mathrm{Cu}-0.6 \% \mathrm{Sn} / \mathrm{SiO}_{2}$, (d) $\mathrm{Cu}-1.2 \% \mathrm{Sn} / \mathrm{SiO}_{2}$ and (e) $\mathrm{Cu}-1.8 \% \mathrm{Sn} / \mathrm{SiO}_{2}$ after $8 \mathrm{~h}$ reaction.
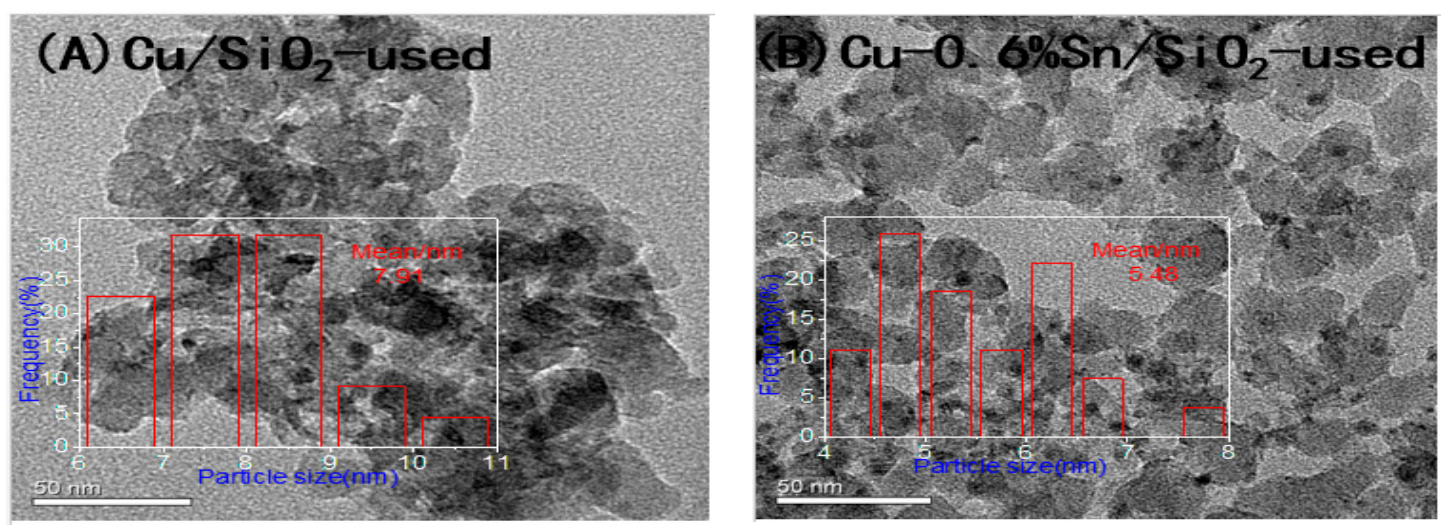

Figure 10. TEM images of used catalysts: $(\mathbf{A}) \mathrm{Cu} / \mathrm{SiO}_{2}$-used $(130 \mathrm{~h})$ and $(\mathbf{B}) \mathrm{Cu}-0.6 \% \mathrm{Sn} / \mathrm{SiO}_{2}$-used $(200 \mathrm{~h})$.

Raman spectroscopy was used to test carbon-coke on the used catalysts. Figure S1 was the Raman spectrum of the $\mathrm{Cu} / \mathrm{SiO}_{2}$-used catalyst and $\mathrm{Cu}-0.6 \% \mathrm{Sn} / \mathrm{SiO}_{2}$-used catalysts. As can be seen from Figure S1, there were two peaks at $1350 \mathrm{~cm}^{-1}$ (amorphous carbon) and $1580 \mathrm{~cm}^{-1}$ (graphitized carbon) in the $\mathrm{Cu} / \mathrm{SiO}_{2}$-used catalyst [23-25] which indicated that carbon deposits were formed in the $\mathrm{Cu} / \mathrm{SiO}_{2}$ catalyst during the reaction. However, the carbon peaks located at 1350 and $1580 \mathrm{~cm}^{-1}$ could not be seen in the $\mathrm{Cu}-0.6 \% \mathrm{Sn} / \mathrm{SiO}_{2}$-used catalysts. This may be due to the fact that the amount of carbon deposition was very small or the distribution of carbon was very uniform. Raman spectroscopic results demonstrated that the doping of tin was beneficial to prevent the formation of carbon deposition.

\section{Experimental Section}

\subsection{Catalyst Preparation}

$\mathrm{Cu}-x \mathrm{Sn} / \mathrm{SiO}_{2}$ was fabricated through ammonia evaporation and subsequent tin impregnation. Silica sol (20 nm, A.R., Alfa Aesar, London, UK) was used as support material. Cupric nitrate and stannous oxide (Sinopharm Chemical Reagent Co., Ltd., Shanghai, China) were prepared as metal precursor salts. All samples were produced to achieve a copper content of $12 \mathrm{wt} \%$ in the catalyst. The tin content was changed to investigate the effect of Sn doping. Firstly, $0.4 \mathrm{~mol} \cdot \mathrm{L}^{-1} \mathrm{Cu}\left(\mathrm{NO}_{3}\right)_{2}$ aqueous solution was prepared in a round-bottomed flask. Ammonia aqueous solution $(28 \mathrm{~mL})$ was 
dropped into $100 \mathrm{~mL}$ of copper nitrate solution with electromagnetic stirring for $30 \mathrm{~min}$. Subsequently, $30 \mathrm{~g}$ of $40 \%$ silica sol was added to the mixture dropwise. The obtained mixture was successively stirred at room temperature for $3 \mathrm{~h}$ and at $90{ }^{\circ} \mathrm{C}$ for another $4 \mathrm{~h} . \mathrm{A} \mathrm{Cu} / \mathrm{SiO}_{2}$ catalyst was prepared after further filtering, washing, drying and calcined. Secondly, $\mathrm{Cu}-x \mathrm{Sn} / \mathrm{SiO}_{2}(x=0.3,0.6,1.2$ and $1.8 \mathrm{wt} \%)$ catalysts were prepared by impregnating the promoter $\mathrm{Sn}^{2+}$ on the $\mathrm{Cu} / \mathrm{SiO}_{2}$ catalysts. A certain amount of stannous oxide was dissolved in $10 \mathrm{~mL}$ of dilute nitric acid solution, and the $\mathrm{pH}$ of the solution was adjusted to $4-5$ by dropping ammonia solution. The required quantities of $\mathrm{Cu} / \mathrm{SiO}_{2}$ sample were immersed into the mixture solution at $25^{\circ} \mathrm{C}$ for $24 \mathrm{~h}$. The obtained slurry was dried at $120^{\circ} \mathrm{C}$ for $10 \mathrm{~h}$ and calcined under argon atmosphere at $450{ }^{\circ} \mathrm{C}$ for $5 \mathrm{~h}$. The resulting catalysts were labelled as $\mathrm{Cu}-x \mathrm{Sn} / \mathrm{SiO}_{2}$, where $x$ refers to the mass content of $\mathrm{Sn}$ in the final catalysts.

\subsection{Characterisation}

ICP-AES was applied to analyse the mass content of active copper and tin additive in the catalysts. The XRD spectra of catalysts were obtained with a D8 ADVANCE XRD (Bruker Company, Karlsruhe, Germany) using $\mathrm{Cu} \mathrm{K} \alpha$ radiation source at $40 \mathrm{kV}$ to investigate the crystalline phases of the samples. The microstructure and active metal particle size were examined by TEM (A JEM 2010 TEM, Japan Electron Optics Laboratory Co. Ltd., Tokyo, Japan) with an acceleration voltage of $200 \mathrm{kV}$. TEM was also used to study the metal particle size and dispersion of samples. The XPS spectra were analysed by an Axis Ultra spectrometer (Shimadzu Corporation, Kyoto, Japan) using monochromatic Mg K $\alpha$ X-ray of $1253.6 \mathrm{eV}$ as the radioactive source to measure the valence state and surface content of metallic elements on the catalysts. All binding energy (BE) values were calibrated according to the BE of carbon $(\mathrm{C} 1 \mathrm{~s}=284.5 \mathrm{eV})$. XAES was also performed to determine the valence state of copper on the catalyst surface. A Micromeritics ASAP 2720 instrument (Micromeritics Instrument Corporation, Norcross, GA, USA) was used to detect the reduction behaviour of $\mathrm{Cu}$ and $\mathrm{Sn}$-promoted catalysts. The temperature of the TPR ranged from 25 to $600{ }^{\circ} \mathrm{C}$ at $5{ }^{\circ} \mathrm{C} \cdot \mathrm{min}^{-1}$, and $45 \mathrm{~mL} / \mathrm{min} 10 \% \mathrm{H}_{2} / \mathrm{Ar}$ was fed into the reactor.

\subsection{Activity Measurements}

The hydrogenation of DMO was operated in a 400-mm long and 6-mm diameter stainless steel miniature reactor equipped with a back-pressure control system. For a typical experiment, $0.5 \mathrm{~g}$ of catalysts was loaded into the reactor, and then a certain amount of $5 \% \mathrm{H}_{2} / \mathrm{Ar}$ atmosphere was introduced to reduce the catalysts. The reduction temperature was increased from room temperature to $300{ }^{\circ} \mathrm{C}$ with a heating rate of $2.5^{\circ} \mathrm{C} \cdot \mathrm{min}^{-1}$ for $4 \mathrm{~h}$. After completing the catalyst reduction process, the system was cooled to the reaction temperature of $200^{\circ} \mathrm{C}$. Feedstock of pure $\mathrm{H}_{2}$ and $15 \mathrm{wt} \% \mathrm{DMO}$ methanol solution were fed into the system. The reactions were conducted at $2.5 \mathrm{MPa}, \mathrm{H}_{2} / \mathrm{DMO}$ molar ratio of 90 and weight hour space velocity of DMO in the range of $0.25-2.0 \mathrm{~h}^{-1}$. Hydrogenation products were analysed on a gas chromatograph (Shimadzu GC-9A, Shimadzu Corporation) equipped with a flame ionisation detector and a Wondacap WAX column $(30 \mathrm{~m} \times 0.53 \mathrm{~mm} \times 1.0 \mu \mathrm{m})$.

\section{Conclusions}

This study focused on the effect of $\mathrm{Sn}^{2+}$ doping on the structure and catalytic performance of $\mathrm{Cu} / \mathrm{SiO}_{2}$ catalysts for the hydrogenation of DMO. The introduction of $\mathrm{Sn}^{2+}$ into $\mathrm{Cu} / \mathrm{SiO}_{2}$ catalysts resulted in distinct changes in catalytic performance. The conversion and selectivity of the catalyst displayed a volcano-like trend with increasing tin content. The optimum amount of tin doping was about $0.6 \%$ of the catalyst. Long-period experimental results showed that the DMO was completely transformed. The selectivity of EG was above $96 \%$ in $\mathrm{Cu}-0.6 \% \mathrm{Sn} / \mathrm{SiO}_{2}$ catalyst, and no decreasing trend was obtained after approximately $200 \mathrm{~h}$. By contrast, the activity and stability of $\mathrm{Cu} / \mathrm{SiO}_{2}$ catalyst declined rapidly. This effect may be attributed to the fact that the addition of a suitable amount of tin could adjust the $\mathrm{Cu}^{0} / \mathrm{Cu}^{+}$ratio reasonably. Furthermore, the $\mathrm{SnO}_{2}$ that formed during reduction segregated the active copper and inhibited the aggregation of copper on the catalyst surface. This phenomenon could be responsible for the increased activity and stability of EG. 
Supplementary Materials: The following are available online at www.mdpi.com/2073-4344/7/4/122/s1, Figure S1: The Raman spectrum of the $\mathrm{Cu} / \mathrm{SiO}_{2}$-used catalyst and $\mathrm{Cu}-0.6 \% \mathrm{Sn} / \mathrm{SiO}_{2}$-used catalysts.

Author Contributions: Bin Dai conceived and designed the experiments, and provided financial support; Chuancai Zhang performed the experiments, analyzed the data and wrote the manuscript; Denghao Wang participated in the operation of experiment and data analysis.

Conflicts of Interest: The authors declare no conflict of interest.

\section{References}

1. Zhang, S.; Liu, Q.; Fan, G.; Li, F. Highly dispersed copper-based catalysts from Cu-Zn-Al layered double hydroxide precursor for gas-phase hydrogenation of dimethyl oxalate to ethylene glycol. Catal. Lett. 2012, 142, 1121-1127. [CrossRef]

2. Chen, L.; Guo, P.; Qiao, M.; Yan, S.; Li, H.; Shen, W.; Xu, H.; Fan, K. Cu/SiO 2 catalysts prepared by the ammonia-evaporation method: Texture, structure, and catalytic performance in hydrogenation of dimethyl oxalate to ethylene glycol. J. Catal. 2008, 257, 172-180. [CrossRef]

3. Yin, A.; Guo, X.; Dai, W.-L.; Li, H.; Fan, K. Highly active and selective copper-containing HMS catalyst in the hydrogenation of dimethyl oxalate to ethylene glycol. Appl. Catal. A 2008, 349, 91-99. [CrossRef]

4. Zhu, Y.Y.; Wang, S.R.; Zhu, L.J.; Ge, X.L.; Li, X.B.; Luo, Z.Y. The influence of copper particle dispersion in $\mathrm{Cu} / \mathrm{SiO}_{2}$ catalysts on the hydrogenation synthesis of ethylene glycol. Catal. Lett. 2010, 135, $275-281$. [CrossRef]

5. Gong, J.; Yue, H.; Zhao, Y.; Zhao, S.; Zhao, L.; Lv, J.; Wang, S.; Ma, X. Synthesis of ethanol via syngas on $\mathrm{Cu} / \mathrm{SiO}_{2}$ catalysts with balanced $\mathrm{Cu}^{0}-\mathrm{Cu}^{+}$sites. J. Am. Chem. Soc. 2012, 134, 13922-13925. [CrossRef] [PubMed]

6. Li, F.; Lu, C.-S.; $\mathrm{Li}, \mathrm{X}$.-N. The effect of the amount of ammonia on the $\mathrm{Cu}^{0} / \mathrm{Cu}^{+}$ratio of $\mathrm{Cu} / \mathrm{SiO}_{2}$ catalyst for the hydrogenation of dimethyl oxalate to ethylene glycol. Chin. Chem. Lett. 2014, 25, 1461-1465. [CrossRef]

7. He, Z.; Lin, H.; He, P.; Yuan, Y. Effect of boric oxide doping on the stability and activity of a Cu-SiO $\mathrm{C}_{2}$ catalyst for vapor-phase hydrogenation of dimethyl oxalate to ethylene glycol. J. Catal. 2011, 277, 54-63. [CrossRef]

8. Yue, H.; Zhao, Y.; Zhao, S.; Wang, B.; Ma, X.; Gong, J. A copper-phyllosilicate core-sheath nanoreactor for carbon-oxygen hydrogenolysis reactions. Nat. Commun. 2013, 4, 2339. [CrossRef] [PubMed]

9. Wang, Y.-N.; Duan, X.; Zheng, J.; Lin, H.; Yuan, Y.; Ariga, H.; Takakusagi, S.; Asakura, K. Remarkable enhancement of $\mathrm{Cu}$ catalyst activity in hydrogenation of dimethyl oxalate to ethylene glycol using gold. Catal. Sci. Technol. 2012, 2, 1637. [CrossRef]

10. Huang, Y.; Ariga, H.; Zheng, X.; Duan, X.; Takakusagi, S.; Asakura, K.; Yuan, Y. Silver-modulated $\mathrm{SiO}_{2}$-supported copper catalysts for selective hydrogenation of dimethyl oxalate to ethylene glycol. J. Catal. 2013, 307, 74-83. [CrossRef]

11. Kaddouri, A.; Mazzocchia, C.; Tempesti, E. Sol-gel processing of copper-chromium catalysts for ester hydrogenation. J. Therm. Anal. Calorim. 1998, 53, 533-545. [CrossRef]

12. Coupé, J.N.; Jordão, E.; Fraga, M.A.; Mendes, M.J. A comparative study of $\mathrm{SiO}_{2}$ supported Rh-Sn catalysts prepared by different methods in the hydrogenation of citral. Appl. Catal. A 2000, 199, 45-51.

13. Luo, G.; Yan, S.; Qiao, M.; Zhuang, J.; Fan, K. Effect of tin on Ru-B $/ \gamma-\mathrm{Al}_{2} \mathrm{O}_{3}$ catalyst for the hydrogenation of ethyl lactate to 1,2-propanediol. Appl. Catal. A 2004, 275, 95-102. [CrossRef]

14. Vicente, A.; Lafaye, G.; Especel, C.; Marécot, P.; Williams, C.T. The relationship between the structural properties of bimetallic $\mathrm{Pd}-\mathrm{Sn} / \mathrm{SiO}_{2}$ catalysts and their performance for selective citral hydrogenation. J. Catal. 2011, 283, 133-142. [CrossRef]

15. Esmaeili, E.; Mortazavi, Y.; Khodadadi, A.A.; Rashidi, A.M.; Rashidzadeh, M. The role of tin-promoted $\mathrm{Pd} / \mathrm{MWNTs}$ via the management of carbonaceous species in selective hydrogenation of high concentration acetylene. Appl. Surf. Sci. 2012, 263, 513-522. [CrossRef]

16. Wang, G.; Wang, H.; Zhang, H.; Zhu, Q.; Li, C.; Shan, H. Highly selective and stable NiSn $/ \mathrm{SiO}_{2}$ catalyst for isobutane dehydrogenation: Effects of Sn addition. Chemcatchem 2016, 8, 3137-3145. [CrossRef]

17. De Oliveira, K.; Pouilloux, Y.; Barrault, J. Selective hydrogenation of methyl oleate into unsaturated alcohols in the presence of cobalt-tin supported over zinc oxide catalysts. J. Catal. 2001, 204, 230-237. [CrossRef] 
18. Lin, H.; Zheng, X.; He, Z.; Zheng, J.; Duan, X.; Yuan, Y. Cu/SiO 2 hybrid catalysts containing HZSM-5 with enhanced activity and stability for selective hydrogenation of dimethyl oxalate to ethylene glycol. Appl. Catal. A 2012, 445, 287-296. [CrossRef]

19. Marchi, A.J.; Fierro, J.L.G.; Santamaria, J.; Monzón, A. Dehydrogenation of isopropylic alcohol on a $\mathrm{Cu} / \mathrm{SiO} 2$ catalyst: A study of the activity evolution and reactivation of the catalyst. Appl. Catal. A 1996, 142, 375-386. [CrossRef]

20. Yin, A.; Guo, X.; Dai, W.-L.; Fan, K. Effect of initial precipitation temperature on the structural evolution and catalytic behavior of $\mathrm{Cu} / \mathrm{SiO}_{2}$ catalyst in the hydrogenation of dimethyloxalate. Catal. Commun. 2011, 12, 412-416. [CrossRef]

21. Ma, X.; Yang, Z.; Liu, X.; Tan, X.; Ge, Q. Dynamic redox cycle of $\mathrm{Cu}^{0}$ and $\mathrm{Cu}^{+}$over $\mathrm{Cu} / \mathrm{SiO}_{2}$ catalyst in ester hydrogenation. RSC Adv. 2015, 5, 37581. [CrossRef]

22. LaGrow, A.P.; Ward, M.R.; Lloyd, D.C.; Gai, P.L.; Boyes, E.D. Visualizing the $\mathrm{Cu} / \mathrm{Cu}_{2} \mathrm{O}$ interface transition in nanoparticles with environmental scanning transmission electron microscopy. J. Am. Chem. Soc. 2017, 139, 179-185. [CrossRef] [PubMed]

23. Goula, M.A.; Charisiou, N.D.; Siakavelas, G.; Tzounis, L.; Tsiaoussis, I.; Panagiotopoulou, P.; Goula, G.; Yentekakis, I.V. Syngas production via the biogas dry reforming reaction over Ni supported on zirconia modified with $\mathrm{CeO}_{2}$ or $\mathrm{La}_{2} \mathrm{O}_{3}$ catalysts. Int. J. Hydrogen Energ. 2016, 1-17. [CrossRef]

24. Papageridis, K.N.; Siakavelas, G.; Charisiou, N.D.; Avraam, D.G.; Tzounis, L.; Kousi, K.; Goula, M.A. Comparative study of $\mathrm{Ni}, \mathrm{Co}, \mathrm{Cu}$ supported on $\gamma$-alumina catalysts for hydrogen production via the glycerol steam reforming reaction. Fuel Process. Technol. 2016, 152, 156-175. [CrossRef]

25. Charisiou, N.D.; Siakavelas, G.; Papageridis, K.N.; Baklavaridis, A.; Tzounis, L.; Avraam, D.G.; Goula, M.A. Syngas production via the biogas dry reforming reaction over nickel supported on modified with $\mathrm{CeO}_{2}$ and/or $\mathrm{La}_{2} \mathrm{O}_{3}$ alumina catalysts. J. Nat. Gas Sci. Eng. 2016, 31, 164-183. [CrossRef]

(c) 2017 by the authors. Licensee MDPI, Basel, Switzerland. This article is an open access article distributed under the terms and conditions of the Creative Commons Attribution (CC BY) license (http:/ / creativecommons.org/licenses/by/4.0/). 